ORIGINAL RESEARCH ARTICLE

\title{
When Commitments Conflict: Making Ethical Decisions Like a Funambulist
}

\author{
Jean Nizet', Pauline Fatien Diochon*, and Lakshmi Balachandran Nair ${ }^{3}$ \\ 'Namur University, Belgium \\ ${ }^{2}$ Grenoble Ecole de Management, F-38000 Grenoble, France \\ ${ }^{3}$ Department of Business and Management, LUISS Guido Carli, 00 197, Rome, Italy
}

\begin{abstract}
Given the complexity of organizations, individuals nowadays are handling an increasing number of commitments. When these commitments come into conflict, they can turn into ethical dilemmas. However, little is known about how individuals make ethical decisions in the face of such conflicting commitments. We investigated this issue within the context of executive coaching, since coaches often interact with multiple stakeholders as part of their assignments. We conducted 37 semi-structured interviews using the critical incident technique, that is, by asking executive coaches to share a situation that was ethically challenging for them. Based on our study, we derive the metaphor of funambulism to depict how individuals make decisions in the case of conflicting commitments. By building on the systemic framework, we show that executive coaches manage an equilibrium 'along the way' through an emergent system of practices, which involves making adjustments that can maintain or restore their system's equilibrium (i.e., compatibility between commitments). This contribution alludes to the dynamic and constructed nature of ethics.
\end{abstract}

Keywords: Ethics; Systemic Approach; Hirschman; Equilibrium; Coaching

Handling Editor:Thomas Roulet; Received: I May 2019; Accepted: 2 April 2020; Published: 19 March 2021

A $s$ part of a trend that has long been rooted in the complexification of organizations, individuals today handle an increasing number of commitments at work, manifested as involvement with and obligations to more and more stakeholders (Meyer \& Herscovitch, 200I). These multiple commitments originate in organizational matrix structures that expose individuals to various hierarchical authorities (Galbraith, 1973; Mintzberg, 1978), in networked organizations where they face several stakeholders (Miles \& Snow, 1986), or in the rise of alternative forms of employment, with the freelancers, external contractors, and other independent professionals of today's workplace (Fleming, 2017; Leighton \& McKeown, 20 I5). The recognition that people are committed to multiple workplace stakeholders (Becker, Kernan, Clark, \& Klein, 20 I 8) helps us understand several important work behaviors, such as job performance, deviance, creativity, well-being, and withdrawal (Becker, 20 I6).

While sometimes portrayed as compatible and even synergetic (Swart, Kinnie, van Rossenberg, \& Yalabik, 2014), these commitments can be conflicting (Becker et al., 2018; CooperHakim \& Viswesvaran, 2005; Reichers, 1986) and have damaging consequences, such as individuals' identification with organizations being challenged, their social identity being called into question, and their overall well-being reduced (George \& Chattopadhyay, 2005). This is why compatibility is often sought to minimize conflicts between these commitments (Meyer, 2016). However, in certain cases, ethical dilemmas emerge as a consequence of multiple, conflicting commitments, and generate severe individual and organizational costs (Kammeyer-Mueller, Simon, \& Rich, 20 12; Nelson William, Weeks, \& Campfield, 2008). Against this backdrop, it is important to understand how individuals make ethical decisions in such conflicting situations. Our research question is therefore: How do individuals make decisions when conflicting commitments create ethical dilemmas for them?

We investigated this question using a sample of executive coaches. Coaches are skilled independent professionals (Graßmann, Schermuly, \& Wach, 2019) called on to support change in organizations (Garvey, 201 I; Gray, Garvey, \& Lane,

*Corresponding author: Pauline Fatien Diochon, Email: Pauline.fatien@grenoble-em.com 
20 16; Salman, 2008). Over the course of their interventions, they interact with multiple stakeholders (Louis \& Fatien Diochon, 2014), typically the recipient of the coaching, his or her manager, and/or his or her HR manager, etcetera. It is also often the case that coaches are in contact with peers and other, more experienced coaches, for example to seek advice on an intervention. In brief, like other professionals, coaches are engaged in a multiplicity of commitments (Olsen, Sverdrup, Nesheim, \& Kalleberg, 2016). Exploring these commitments from an ethics angle is especially important for such an emerging profession seeking to establish legitimacy (Bachkirova, 2017; lordanou \& Williams, 2017; Louis \& Fatien Diochon, 2019).

Our article is structured as follows. Firstly, we introduce the topic of conflicting commitments. This topic encouraged us to go beyond the dominant essentialist perspectives found in the ethics literature. Secondly, we present the research methodology used - the critical-incident interview technique we used to collect data from our sample of 37 coaches, as well as our analytical framework (Exit, Voice, and Loyalty [EVL] framework [Hirschman, 1970]). We then present our findings, showing that the decision made in the case of an ethical dilemma requires adjustments from the individual to maintain or restore compatibility between commitments. Finally, in our discussion, building on the systemic framework (Bateson, 1972; Watzlawick, Beavin Bavelas, \& Jackson, 1968), we depict ethical decision-making using the metaphor of funambulism, where the individual is managing equilibrium 'along the way.' We therefore suggest portraying ethics as an emergent system of practices, one that is made up of interrelated adjustments that individuals use to maintain or restore the system's equilibrium, that is, compatibility between commitments. This contribution alludes to the dynamic and constructed nature of ethics (Simpson, 2009; Sonenshein, 2007, 2009).

\section{Literature review: Making ethical decisions with feet in multiple camps}

\section{Individuals increasingly handle multiple commitments}

Over the years, with the complexification of organizations, individuals have been handling an increasing number of commitments. As early as the 1960s and 1970s, some organizations replaced unique lines of command with matrix structures (Galbraith, 1973; Mintzberg, 1978) where managers belonged to several entities, handling both functional and project-based responsibilities, which in turn translated into the need to report to several authoritative figures. Later on, in the 1990s, multi-commitments were boosted with the rise of new forms of organizations, such as networked organizations, where individuals engaged with suppliers, subcontractors, clients, and other stakeholders. More recently, commitments have continued to expand with the openness of organizations and emergence of multi-stakeholder movements, such as open collaboration (de Vaujany, Leclercq-Vandelannoitte, \& Holt, 2020) and cross-sector governance structures (Whelan, de Bakker, Den Hond, \& Muthuri, 2019).

Although it has been conceptualized in a variety of ways, Meyer and Herscovitch (200I, p. 30I) suggest defining commitment as a "force that binds an individual to a course of action of relevance to one or more targets." These targets range from organizations, occupations, and professions to teams, leaders, goals, unions, and so forth (Biétry, Creusier, Laroche, \& Camus, 20I4). It is important to understand that employees experience commitments to multiple targets, which "contributes to understanding and predicting important work behaviors" (Becker, 2016, p. 46), because multi-commitments challenge the perimeter of the decision with a modification of its constraints, as well as in its impact. They especially challenge identification with one's organization, social identity, and acceptance of uncertainty (George \& Chattopadhyay, 2005). Therefore, recognizing that conflicts of commitments occur, and the fact that they "can have negative consequences for employee attitudes and action" (Becker, 2016, p. 46), requires further exploration.

Typically, conflicts of commitments can emerge in employer and client relationships (Olsen et al., 2016) when clients request more activities than contracted. They can also develop between one's profession or education and codes of ethics (Yalabik, van Rossenberg, Kinnie, \& Swart, 20I5). This is common when a client's request falls outside the scope of the profession concerned. Conflicts can also arise within teams, especially when work is organized into project teams or practice groups where members work together to produce and organize knowledge to maximize client benefits (Yalabik et al., 20।5).

When multiple commitments come in conflict, they can turn into ethical dilemmas. Dilemmas can be defined as two or more quests that cannot be met conjointly (Greimas, 1966; Piret, Nizet, \& Bourgeois, 1996). The protagonist pursuing these quests in a given context thus has to choose between partially satisfying situations (Piret et al., 1996). We will talk about an ethical dilemma when these multiple quests raise an ethical issue.

Ethical dilemmas generate several costs for individuals (Kammeyer-Mueller et al., 2012) and their organizations (Nelson William et al., 2008), such as psychological, emotional, operational, legal, marketing, and public relations costs. Psychological and emotional costs for example include distress, guilt, emotional exhaustion, and lower job satisfaction (Kammeyer-Mueller et al., 20I2). It is therefore 
important to better understand how individuals make ethical decisions, especially in the context of conflicting commitments.

Our next section introduces the topic of ethics and the need to go beyond an essentialist approach to understand ethical dilemmas in the case of multiple commitments.

\section{Going beyond an essentialist approach to ethics in order to embrace challenges that arise from multiple commitments}

The descriptions of what constitutes an ethical issue and how people make an ethical decision vary greatly depending upon the ontology adopted.

According to the dominant essentialist and objectivist ontology, ethical issues are portrayed as objective entities that are external to individuals. They are "out there," independent of individuals and context. And their resolution involves the application of a "logical, rational, and deliberative cognitive process" (Schwartz, 2016, p. 758) using externally given rules (Sonenshein, 2007, 2009). Here ethics is located in the individual, as a property: individuals, depending on their "character" (Jones, Parker, \& ten Bos, 2005, p. 4), traits, and abilities, will reach a certain moral judgment stage (Rest, 1986), or development stages (Kohlberg, 1973) that will predict a certain reasoning. These perspectives have a tendency to "foreclose" (Jones et al., 2005, p. 4) ethics by eschewing complexity. This includes "foreclosing society" (ibid, p. 4) with neglect of social structures, forgetting that decisions always take place in a context, "foreclosing 'the ethical"' (ibid, p. 5) with a narrow definition of what should count as "the ethical" (ibid, p. 5), and "foreclosing the goals of ethics" (ibid, p. 5) with a tendency to favor reassuring perspectives that prescribe how to do the right thing, rather than exposing us to the "undecidability" of endless openness (Derrida, 1992, p. 131) and the disrupting difference of the Other (Levinas, 1991).

Therefore, alternative perspectives in ethics that adopt a more constructive view will emphasize how ethical decisions unfold according to an interpretive temporal process that cannot exclude situations and others (Parmar, 2014; Reinecke \& Ansari, 2015; Sonenshein, 2007). Ethical decisions rather appear to emerge (Sonenshein, 2009) within individuals and should be understood in their contexts. In particular, individuals take others into account while making ethical decisions when they decide to share with them their opinion or concerns (e.g., to provide constructive feedback or denounce inappropriate behaviors (Charreire Petit, 2008; Charreire Petit \& Cusin, 2013); when they decide to remain silent (e.g., to avoid hurting them), or when they put an end to a relationship (to avoid further deterioration) (Hooghiemstra \& van Manen, 2002; Keeley \& Graham, 1991)). These ethical options comply with Hirschman's EVL model (1970), which we used in our data analysis. Further details about our research methodology are provided in the following section.

\section{Research methodology}

\section{Research context: Executive coaching}

We chose to study how individuals make ethical decisions when they experience conflicting commitments by using a sample of executive coaches. The qualitative data used in this article is part of a larger project on ethics in coaching. Given the diversity of the topics covered under the project, it was not feasible to produce a single integrative article that presents all the results from the entire data set in a meaningful way. Each article developed from this data set (Fatien Diochon \& Nizet, 2015, 2019; Pichault, Fatien Diochon, \& Nizet, 2020) addresses a different research question, uses different relevant literature, and has a distinct purpose.

Coaches are skilled independent professionals (Graßmann et al., 2019) called on to support change, learning, and performance in organizations (Garvey, 20 I I; Graßmann, Schölmerich, \& Schermuly, 2020; Gray et al., 2016). They intervene at the individual, team, and/or organizational levels. Coaches typically facilitate situations that include transitioning to a new position, building assertiveness, promoting better team management, and enhancing cohesion (Gray et al., 2016). It is important to note that the expertise of coaches is drawn more from their abilities to design a supportive process than from specific knowledge of a domain or industry. In brief, a coach's role can be summarized as providing a holding space, a safe container, likely to support the exploration of new behaviors (Dubouloy, 2004; Western, 2012, 2017).

Given the nature of their interventions, coaches handle multiple commitments and agendas (Louis \& Fatien Diochon, 2014; Salman, 2019). These commitments involve internal (within the client organization) as well as external stakeholders. Internal stakeholders include not only the direct recipient of the coaching service (also called the coachee), with whom the working alliance is perceived as the key (Graßmann et al., 2019), but also the HR Manager, the coachee's manager, and the coachee's colleagues. External stakeholders include coaching associations, coaching schools, other coaches, and sometimes even a coach's personal connections. These multiple commitments make coaching an ambiguous practice (Natale \& Diamante, 2005; Nizet \& Diochon, 2012) in which the coach wears multiple, sometimes contradictory hats (Stein, 2009). While the ability to navigate within these multiple camps is perceived as the key for an activity on its way towards professionalization and legitimization (Gray et al., 2016), it is far from straightforward. There are times when holding multiple roles or facing contradictory requests becomes extremely difficult, to the point that it may raise ethical dilemmas (Fatien Diochon 
\& Nizet, 2015, 2019; Louis \& Fatien Diochon, 2019). Exploring how coaches make ethical decisions when they experience conflicting commitments is the focus of this study.

\section{Research method: Critical incident technique}

Given our focus on ethical decision-making, we needed a research method suited for such challenging situations and interviewees' reactions or coping techniques in the face of subsequent situational demands (Arthur, 200 I). Consequently, we used the critical incident technique (CIT) (Flanagan, 1954) to interview coaches about their personal experiences with ethical dilemmas.

Developed by Flanagan in the context of World War II for the purposes of military job analyses, the CIT was designed to collect real-life activities and behaviors perceived either as outstandingly effective or ineffective with respect to meeting the general aims of their job (Flanagan, 1954, p. 338). It has now become an established technique with a proven record as an investigative tool in a wide range of academic settings (Butterfield, Borgen, Amundson, \& Maglio, 2005; Chell, 2004).

To reflect the underlying flexibility of the CIT, we specifically used a variant of the method called "Balanced Experiential Inquiry Exercise."This technique was developed by Sekerka, Godwin, and Charnigo (20/2) and has often been used in the study of ethical topics. This CIT technique invites interviewees to share the critical incidents they encountered, diagnose the difficulties involved in the situation, and comprehend the support and abilities that they used to proceed with ethical action.

\section{Data collection}

\section{Critical incidents}

The objective of the CIT here was to "gain an understanding from the perspective of the individual, taking into account cognitive, affective, and behavioral elements" (Chell, 2004, p. 48). Critical incidents in this situation pertained to the recollection of a "situation [that] may have made it difficult for [people] to act, to know what to do, or to determine how to resolve the situation." The interviewer invited the interviewees to "think back to a time in [their] coaching practice when [they] faced an ethical challenge." Interviewees were then asked 3 main reflective questions: (I) what was the ethical challenge? (2) what were you thinking at the time? (3) what were you feeling at the time? They were also asked further follow-up questions (See Appendix I for the complete interview topic guide). In line with our constructive ontology, we considered that the dilemma was ethical as long as the interviewee defined it as such.
The interviews were conducted in French. Two interviewers conducted the interviews via Skype. One critical incident was discussed per interview, resulting in a total of 37 incidents. Thirty-six (97\%) of the incidents were usable: one incident had to be excluded since that particular interviewee did not want to share further information about the critical incident encountered. The interviews were tape recorded and verbatim transcribed professionally. Transcripts had an average length of 15 single pages, and interviews lasted an average of $50 \mathrm{~min}$ (see further details in Table I below).

\section{Interviewee characteristics}

All 37 interviewees self-selected and volunteered for this study and personally contacted the researcher after reading a call for participation in the newsletter of their respective coaching association, either Société Française de Coaching - SFC (French Coaching Association) - or the French branch of the International Coaching Federation (ICF). This self-selection was advantageous given the high level of self-disclosure and voluntariness involved in CIT interviews. The two coaching associations were chosen as they are considered the two most popular coaching associations in France. Eighteen of our interviewees were from the SFC and 19 from the ICF, representing $7 \%$ and $12 \%$ of the certified population of each association, respectively. All our interviewees were "certified" by one of these two associations, meaning they went through a selective process where the coach demonstrated his or her skills and ethics in respect of the criteria of each association. Twenty-five interviewees were women and 12 were men; a proportion similar to the wider population of coaches, $67 \%$ of whom were women (ICF, 20 I6). Ages ranged from 30 to 60 years old, with 5 to 15 years of coaching practice. Table I provides the list of our interviewees, their gender, duration of the interviews, the times the interviews were conducted, as well as a summary of the interviewees' conflicting commitments. To ensure anonymity, we use pseudonyms for the interviewees (coaches) in this manuscript.

\section{Data analysis}

Analyses were conducted on the original (French) interview transcripts. For the paper, the authors then translated verbatim the transcripts into English with the support of a bilingual professional copy-editor. The interviews were jointly analyzed by two of the authors who had a shared understanding of the data.

In line with the process recommended to analyze critical incidents (Butterfield et al., 2005), our analysis included two steps. The first involved identifying a pattern for critical incidents that could be applied to each situation described by the interviewees. The second relates to the determination of the 
Table I. List of the 37 interviews with descriptions of the conflicting commitments

\begin{tabular}{|c|c|c|}
\hline $\begin{array}{l}\text { Coaching association } \\
\text { Pseudonym (Gender) }\end{array}$ & $\begin{array}{l}\text { Month and year } \\
\text { of interview } \\
\text { Duration }\end{array}$ & Conflicting commitment \\
\hline $\begin{array}{l}\text { SCFI } \\
\text { Sophia (F) }\end{array}$ & $\begin{array}{l}\text { May } 2012 \\
53 \text { mins }\end{array}$ & $\begin{array}{l}\text { Sophia suspects that her coach's boss is manipulative and dangerous. Should Sophia advise her coach to protect } \\
\text { herself from her boss, or should Sophia stay within the boundaries of the initial contract and remain more neutral? }\end{array}$ \\
\hline $\begin{array}{l}\text { SFC2 } \\
\text { Alex (M) }\end{array}$ & $\begin{array}{l}\text { May } 2012 \\
63 \text { mins }\end{array}$ & $\begin{array}{l}\text { Alex gradually realizes that his coachee's team is in a state of profound suffering. Should he disclose this situation } \\
\text { to his coachee's boss to help resolve things? Or will the disclosure be damaging for his client? }\end{array}$ \\
\hline $\begin{array}{l}\text { SFC3 } \\
\text { Judy (F) }\end{array}$ & $\begin{array}{l}\text { May } 2012 \\
70 \text { mins }\end{array}$ & $\begin{array}{l}\text { Judy is torn between honoring the pressing request of her coachee's director for rapid coaching results and } \\
\text { respecting her coachee's lesser demand for change. }\end{array}$ \\
\hline $\begin{array}{l}\text { SFC4 } \\
\text { Ruth (F) }\end{array}$ & $\begin{array}{l}\text { May } 2012 \\
48 \text { mins }\end{array}$ & $\begin{array}{l}\text { A very wealthy coachee plays with Ruth's agenda and makes unusual requests. She wonders how much she can } \\
\text { challenge him on his requests. What would her coaching peers do in this situation? }\end{array}$ \\
\hline $\begin{array}{l}\text { SFC5 } \\
\text { Bob (M) }\end{array}$ & $\begin{array}{l}\text { May } 2012 \\
67 \text { mins }\end{array}$ & $\begin{array}{l}\text { Bob's coachee finds his current company environment detrimental and wants to leave. He has asked Bob to } \\
\text { coach him to prepare for this departure. Bob finds this request unexpected, but he still feels obliged to follow } \\
\text { the parameters of the original contract. }\end{array}$ \\
\hline $\begin{array}{l}\text { SFC6 } \\
\text { Flora (F) }\end{array}$ & $\begin{array}{l}\text { May } 2012 \\
47 \text { mins }\end{array}$ & $\begin{array}{l}\text { When Flora realizes that her coachee is a victim of moral harassment by his direct supervisor, she wonders } \\
\text { whether she should discuss this realization with her coachee even though he never requested such a discussion. }\end{array}$ \\
\hline $\begin{array}{l}\text { SFC7 } \\
\text { Marie (F) }\end{array}$ & $\begin{array}{l}\text { Jun } 2012 \\
53 \text { mins }\end{array}$ & $\begin{array}{l}\text { When she hears that her coachee might be fired if he does not change his behavior, Marie wonders how she } \\
\text { can still help him and at the same time maintain a good relationship with the HR Manager. }\end{array}$ \\
\hline $\begin{array}{l}\text { SFC8 } \\
\text { Patricia (F) }\end{array}$ & $\begin{array}{l}\text { Jun } 2012 \\
52 \text { mins }\end{array}$ & $\begin{array}{l}\text { Patricia is struck by the HR Manager's request to use coaching to "get rid of" the coachee, Helen, through inter- } \\
\text { nal mobility, and to pass on the message that she should change her attire. Patricia feels instrumentalized and } \\
\text { dislikes this organizational culture of secrecy. }\end{array}$ \\
\hline $\begin{array}{l}\text { SFC9 } \\
\text { David (M) }\end{array}$ & $\begin{array}{l}\text { Jun } 2012 \\
38 \text { mins }\end{array}$ & $\begin{array}{l}\text { David gradually realizes that his coachee is in a general state of exhaustion caused by a dash-for-profit organiza- } \\
\text { tional culture. He expresses his disgust for this type of company, which contradicts his value system. However, he } \\
\text { is acting as a sub-contractor and needs to meet the company's expectations. }\end{array}$ \\
\hline $\begin{array}{l}\text { SFCIO } \\
\text { Julie (F) }\end{array}$ & $\begin{array}{l}\text { Jun } 2012 \\
56 \text { mins }\end{array}$ & $\begin{array}{l}\text { Julie realizes that her coachee is neglecting major safety rules and wants to sort out the situation alone. But she } \\
\text { is really concerned and wonders whether she should shortcut her coachee and talk to HR directly. }\end{array}$ \\
\hline $\begin{array}{l}\text { SFCII } \\
\text { Meryl (F) }\end{array}$ & $\begin{array}{l}\text { Jun } 2012 \\
53 \text { mins }\end{array}$ & $\begin{array}{l}\text { Meryl does not know how to handle the HR request to coach Marie to "endorse the managerial uniform of the } \\
\text { company." While this framing of coaching totally contradicts her vision of the practice, she is mindful of the need } \\
\text { to maintain a good relationship with the client. }\end{array}$ \\
\hline $\begin{array}{l}\text { SFCI } 2 \\
\text { Paul-Roger (M) }\end{array}$ & $\begin{array}{l}\text { Jun } 2012 \\
45 \text { mins }\end{array}$ & $\begin{array}{l}\text { While Paul-Roger is supposed to coach Joshua to be "a more assertive leader," he realizes that Joshua's difficul- } \\
\text { ties are rooted in a dysfunctional organizational culture. How can he then help the coachee? }\end{array}$ \\
\hline $\begin{array}{l}\text { SFCI3 } \\
\text { Amanda (F) }\end{array}$ & $\begin{array}{l}\text { Aug } 2012 \\
58 \text { mins }\end{array}$ & $\begin{array}{l}\text { Amanda gradually realizes that her coachee is a victim of moral harassment. She wonders whether she can } \\
\text { divulge this secret information in a way that safeguards the anonymity of her coachee. }\end{array}$ \\
\hline $\begin{array}{l}\text { SFCI } 4 \\
\text { Jose (M) }\end{array}$ & $\begin{array}{l}\text { Sept } 2012 \\
30 \text { mins }\end{array}$ & $\begin{array}{l}\text { Jose, a pacifist, is offered a coaching contract in the military industry. He feels extremely conflicted that he is } \\
\text { betraying his values while at the same time very excited about this challenging business opportunity. }\end{array}$ \\
\hline $\begin{array}{l}\text { SFCI } 5 \\
\text { Caroline (F) }\end{array}$ & $\begin{array}{l}\text { Oct } 2012 \\
52 \text { mins }\end{array}$ & $\begin{array}{l}\text { Given the burden weighing on her coachee, Caroline is tempted to step outside of her usual coaching role and } \\
\text { do everything she can to help her "succeed." But this would imply departing from the neutral role expected of } \\
\text { a coach, even hiding important information from the organization. }\end{array}$ \\
\hline $\begin{array}{l}\text { SFCI } 6 \\
\text { Mila (F) }\end{array}$ & $\begin{array}{l}\text { Oct } 2012 \\
46 \text { mins }\end{array}$ & $\begin{array}{l}\text { Mila does not feel comfortable when the initial context of her coaching contract changes. She feels that she is betray- } \\
\text { ing the initial sponsor who pays her, and continuing would mean participating in organizational "power games." }\end{array}$ \\
\hline $\begin{array}{l}\text { SFCI } 7 \\
\text { Diego (M) }\end{array}$ & $\begin{array}{l}\text { Nov } 2012 \\
37 \text { mins }\end{array}$ & $\begin{array}{l}\text { After moving to a new department, Diego's coachee wants to hide from his new boss the fact that he is being } \\
\text { coached. Diego feels uncomfortable with this request; he wants to confront his coachee about his rationale } \\
\text { but fears a loss of trust. }\end{array}$ \\
\hline $\begin{array}{l}\text { SFCI } 8 \\
\text { Virginia (F) }\end{array}$ & $\begin{array}{l}\text { Dec } 2012 \\
58 \text { mins }\end{array}$ & $\begin{array}{l}\text { When her coaching contract ends, Virginia is taken aback to hear from the HR manager that he is not satisfied } \\
\text { with the outcomes. She really did not expect this reaction and wonders how to handle it; should she talk to the } \\
\text { coachee or challenge HR about this feedback? }\end{array}$ \\
\hline $\begin{array}{l}\text { ICFI } \\
\text { Chloe (F) }\end{array}$ & $\begin{array}{l}\text { Jul } 2013 \\
60 \text { mins }\end{array}$ & $\begin{array}{l}\text { After a difficult start to the coaching job, HR keeps changing the objectives of the contract. How can Chloe } \\
\text { manage this relationship with HR, and still be useful to her coachee? }\end{array}$ \\
\hline $\begin{array}{l}\text { ICF2 } \\
\text { Jacky (F) }\end{array}$ & $\begin{array}{l}\text { Jul } 2013 \\
78 \text { mins }\end{array}$ & $\begin{array}{l}\text { During a } 360^{\circ} \text { debriefing with a team, Jacky is puzzled when a doctor acts violently toward a nurse; twisting her } \\
\text { arm and making a chair fall over. Jacky wonders how she allowed this incident to happen, and how best to react } \\
\text { now towards the team, the nurse, and the doctor. }\end{array}$ \\
\hline $\begin{array}{l}\text { ICF3 } \\
\text { Tom (M) }\end{array}$ & $\begin{array}{l}\text { Jul } 2013 \\
45 \text { mins }\end{array}$ & $\begin{array}{l}\text { Facing huge pressure from HR for a successful coaching intervention, Tom fears that he will be discredited } \\
\text { if he "fails," but he does not want to "abandon" a coachee in need either. }\end{array}$ \\
\hline $\begin{array}{l}\text { ICF4 } \\
\text { Gabriella (F) }\end{array}$ & $\begin{array}{l}\text { Jul } 2013 \\
51 \text { mins }\end{array}$ & $\begin{array}{l}\text { While her coachee is on sick leave, Gabriella receives a call from HR letting her know that some of her coachee's } \\
\text { colleagues are accusing her of moral harassment. Gabriella is taken aback and does not know how to handle this } \\
\text { confidential information. Should she call back and challenge HR, or should she talk to her coachee? }\end{array}$ \\
\hline
\end{tabular}


Table I. (Continued) List of the 37 interviews with descriptions of the conflicting commitments

\begin{tabular}{|c|c|c|}
\hline $\begin{array}{l}\text { Coaching association } \\
\text { Pseudonym (Gender) }\end{array}$ & $\begin{array}{l}\text { Month and year } \\
\text { of interview } \\
\text { Duration }\end{array}$ & Conflicting commitment \\
\hline $\begin{array}{l}\text { ICF5 } \\
\text { Madeline (F) }\end{array}$ & $\begin{array}{l}\text { Jul } 2013 \\
46 \text { mins }\end{array}$ & $\begin{array}{l}\text { Madeline and her colleague are on a joint coaching job in a company. She receives two calls a few months apart } \\
\text { from the HR manager and the director, asking to modify the initial coaching request. How should they handle } \\
\text { this request made behind the coachee's back? }\end{array}$ \\
\hline $\begin{array}{l}\text { ICF6 } \\
\text { Lucy (F) }\end{array}$ & $\begin{array}{l}\text { Jul } 2013 \\
41 \text { mins }\end{array}$ & $\begin{array}{l}\text { After a meeting with the HR Manager and her coachee, Lucy is very surprised to hear that HR is asking for a } \\
\text { written report on the coachee's progress. This contradicts previous agreements and challenges the confidential- } \\
\text { ity of the mission. }\end{array}$ \\
\hline $\begin{array}{l}\text { ICF7 } \\
\text { Ryan (M) }\end{array}$ & $\begin{array}{l}\text { Aug } 2013 \\
52 \text { mins }\end{array}$ & $\begin{array}{l}\text { Ryan is very surprised when three female executives from the same organization independently ask him to } \\
\text { coach them to leave the company. He wonders whether he should protect them from the detrimental organi- } \\
\text { zational culture or stay loyal to the paying sponsor. }\end{array}$ \\
\hline $\begin{array}{l}\text { ICF8 } \\
\text { Vincent (M) }\end{array}$ & $\begin{array}{l}\text { Aug } 2013 \\
52 \text { mins }\end{array}$ & $\begin{array}{l}\text { Vincent coaches a director who then asks him to coach his female colleague. After this second job, the latter } \\
\text { maneuvers against the director who ends up getting fired. Feeling betrayed by the female executive, Vincent } \\
\text { wonders about next steps and his future with this company. }\end{array}$ \\
\hline $\begin{array}{l}\text { ICF9 } \\
\text { Beth (F) }\end{array}$ & $\begin{array}{l}\text { Aug } 2013 \\
56 \text { mins }\end{array}$ & $\begin{array}{l}\text { Beth is solicited by her neighbor, Melissa, for a team coaching job in Melissa's company. Melissa quickly wants to } \\
\text { benefit from individual coaching sessions. Nadine feels uncomfortable with this request and is about to share } \\
\text { her discomfort with Melissa but is unsure of her reaction. }\end{array}$ \\
\hline $\begin{array}{l}\text { ICFIO } \\
\text { Sandro (M) }\end{array}$ & $\begin{array}{l}\text { Aug } 2013 \\
78 \text { mins }\end{array}$ & $\begin{array}{l}\text { Sandro senses a lack of emotional connection with his coachee. He wonders whether he should share this } \\
\text { impression. Will he be abusing his power or offering insight to the client? }\end{array}$ \\
\hline $\begin{array}{l}\text { ICF I I } \\
\text { Nick (M) }\end{array}$ & $\begin{array}{l}\text { Aug } 2013 \\
33 \text { mins }\end{array}$ & $\begin{array}{l}\text { Nick is very surprised to find that, after signing a coaching contract, HR is questioning his fees. Despite the } \\
\text { commercial risks, Nick would like to confront them to point out the organization's wider dysfunction. }\end{array}$ \\
\hline $\begin{array}{l}\text { ICFI } 2 \\
\text { Monique (F) }\end{array}$ & $\begin{array}{l}\text { Sept } 2013 \\
47 \text { mins }\end{array}$ & $\begin{array}{l}\text { Ron asks Monique if she would like to coach an employee in the organization where Ron is already coaching a } \\
\text { client. Monique is very tempted but hesitates because she realizes that she is already coaching someone from } \\
\text { that company, and it is never good to coach two people from the same team. }\end{array}$ \\
\hline $\begin{array}{l}\text { ICFI } 3 \\
\text { Laetitia (F) }\end{array}$ & $\begin{array}{l}\text { Sept } 2013 \\
67 \text { mins }\end{array}$ & $\begin{array}{l}\text { Laetitia does not know how to handle a request by her coachee (a very wealthy and influential person in the } \\
\text { region) to work on his communication campaign as it falls outside the scope of her coaching duties (it is a con- } \\
\text { sulting job). }\end{array}$ \\
\hline $\begin{array}{l}\text { ICFI } 4 \\
\text { Stephany (F) }\end{array}$ & $\begin{array}{l}\text { Oct } 2013 \\
42 \text { mins }\end{array}$ & $\begin{array}{l}\text { As she is coaching more and more employees from the same company, Stephany thinks that she is losing the } \\
\text { distance and conditions required to coach. Given the commercial interests, she wonders whether she should } \\
\text { stop working for the company. }\end{array}$ \\
\hline $\begin{array}{l}\text { ICFI } 5 \\
\text { Amy (F) }\end{array}$ & $\begin{array}{l}\text { Oct } 2013 \\
40 \text { mins }\end{array}$ & $\begin{array}{l}\text { When she learns that her coachee's husband has attempted suicide, Amy wonders about her coachee's health: } \\
\text { Is she experiencing burnout? How much should Amy share with the HR Manager? }\end{array}$ \\
\hline $\begin{array}{l}\text { ICF I } 6 \\
\text { Maya (F) }\end{array}$ & $\begin{array}{l}\text { Oct } 2013 \\
52 \text { mins }\end{array}$ & $\begin{array}{l}\text { During a three-way meeting, Maya realizes that the director and the coachee have very different interpretations } \\
\text { of the coaching context and objectives. She fears being caught up in power games and a culture of "double } \\
\text { discourse." }\end{array}$ \\
\hline $\begin{array}{l}\text { ICF I } 7 \\
\text { Alice (F) }\end{array}$ & $\begin{array}{l}\text { Nov } 2013 \\
57 \text { mins }\end{array}$ & $\begin{array}{l}\text { Alice is astonished by the objectives set for her coaching contract. Her client requires her coachee to make "a } \\
\text { giant leap." She wonders whether she should share her doubts with the coachee. }\end{array}$ \\
\hline $\begin{array}{l}\text { ICFI } 8 \\
\text { Samantha (F) }\end{array}$ & $\begin{array}{l}\text { Nov } 2013 \\
43 \text { mins }\end{array}$ & $\begin{array}{l}\text { Samantha is very angry with the HR manager, who asks for directive coaching, framing it as a "polishing tool." She } \\
\text { regrets having missed an opportunity to better explain what coaching is at the beginning of the job. What should she } \\
\text { do now? }\end{array}$ \\
\hline $\begin{array}{l}\text { ICFI9 } \\
\text { Dorian (M) }\end{array}$ & $\begin{array}{l}\text { Nov } 2013 \\
47 \text { mins }\end{array}$ & $\begin{array}{l}\text { When a coaching contract ends, Dorian receives a call from the HR Manager letting him know that he is dissatisfied } \\
\text { with the outcomes. Should Dorian remain silent about the contents of the completed job, at the risk of being per- } \\
\text { ceived as inefficient and discrediting a whole profession? Or should he obey the HR Manager's request, break the } \\
\text { confidentiality clause, and potentially provide information that could prove harmful for the coachee? }\end{array}$ \\
\hline
\end{tabular}

F: Female; M: Male; SFC: Société Française de Coaching; ICF: International Coach Federation.

frame of reference (Nair, 2018) to characterize the nature of the reaction. Table 2 summarizes these two steps along with data collection and a discussion of the findings.

\section{Step I. Identifying a pattern of critical incidents}

As we were analyzing the ethical dilemmas shared by coaches, a pattern emerged that could be applied to each situation described by individual interviewees. This pattern revealed three phases: (I) the initial situation, characterized by compatibility of commitments; (2) the emergence of the ethical dilemma; when the initial compatibility of commitments is challenged leading to the coach's experience of conflicting commitments; (3) the resolution of the ethical dilemma, which entails restoring compatibility between the commitments. The criteria the coaches used to make their decisions range from a 
Table 2. Summary of research process

\begin{tabular}{|c|c|c|}
\hline Methodology & $\begin{array}{l}\text { Frame of reference } \\
\text { (where relevant) }\end{array}$ & Activities involved \\
\hline Data collection & $\begin{array}{l}\text { Balanced experiential } \\
\text { inquiry exercise (critical } \\
\text { incident technique) }\end{array}$ & $\begin{array}{l}\text { The interviewer invited the interviewees to "think back to a time in [their] coaching practice when [they] were } \\
\text { faced with an ethical challenge." Interviewees were then asked three main reflective questions: (I) What was the } \\
\text { ethical challenge? (2) What were you thinking at the time? (3) What were you feeling at the time? With further } \\
\text { follow-up questions. }\end{array}$ \\
\hline $\begin{array}{l}\text { Data analysis } \\
\text { (Step I) }\end{array}$ & - & $\begin{array}{l}\text { The authors identified a pattern in the situations encountered by the interviewees. This pattern comprises three } \\
\text { phases and allows the idea of adjustments to emerge. }\end{array}$ \\
\hline $\begin{array}{l}\text { Data analysis } \\
\text { (Step 2) }\end{array}$ & $\begin{array}{l}\text { EVL analytical } \\
\text { framework }\end{array}$ & The coders used the EVL analytical framework to characterize the nature of the adjustments. \\
\hline $\begin{array}{l}\text { Findings and } \\
\text { discussion }\end{array}$ & $\begin{array}{l}\text { Systemic theoretical } \\
\text { framework }\end{array}$ & $\begin{array}{l}\text { The authors used the systemic framework to theorize the adjustment process, defining ethics as a practice } \\
\text { of equilibrium through a series of interrelated adjustments. }\end{array}$ \\
\hline
\end{tabular}

EVL: Exit, Voice, and Loyalty.

conflict with the law, to conflicts with the professional code of their association, with their values and beliefs (e.g., religious, political), and/or with their emotions.

We have thus broken down each of the 37 ethical dilemmas into these three phases. Over the course of this analysis, we discovered that compatibility between commitments, both in phases I and 3, was not a given, but rather something achieved in a dynamic way through what we call 'adjustments.' We therefore looked for a framework that could describe the nature of the adjustments. This is explained next in Step 2.

\section{Step 2. Analyzing the nature of the adjustments: EVL framework}

To identify an analytical framework that could help us to code the nature of coaches' adjustments, we followed an abductive approach, which involves the continuous application of various frameworks to the data (Dunne \& Dougherty, 2016), with several frameworks tested and dismissed. Eventually, this led to the adoption of Hirschman's EVL model (1970) as our analytical framework. Now established as a model through which researchers can understand the behaviors of actors in situations of dissatisfaction or conflict (Czarniawska, 2017), EVL was developed by Hirschman to capture what happens when individuals are "subject to lapses from efficient, rational, law-abiding, virtuous, or otherwise functional behaviors" (Hirschman, 1970, p. I) and has since been applied to various populations and contexts (Dowding, John, Mergoupis, \& van Vugt, 2000).

Exit happens when people cease their participation in an organization to avoid objectionable consequences, for example "some customers stop buying the firm's products or some members leave the organization" (Hirschman, 1970, p. 4). Voice entails articulating dissatisfaction and critical views in order to change organizational consequences; it comprises "any attempt at all to change an objectionable state of affairs, not only by petitioning to management or higher authorities, but also through protests including the mobilization of the public opinion" (Hirschman, 1970, p. 30). Loyalty is more loosely defined by Hirschman, but can be understood as the maintenance of attachment to the organization. These reactions, in particular exit and voice, are portrayed by Hirschman (1970, p. 24) as "feedback mechanisms", acting as a "reaction function" (ibid, p. 23) to alert organizations that "something is amiss" (ibid, p. 24), and they usually lead organizations to corrective actions. In some circumstances, however, they can lead to destruction, as shown by Hirschman in his analysis of the fall of the communist regime of East Germany (Hirschman, 1993). While originally Hirschman and most of his successors applied these reactions to an organization, we have extended them to stakeholders, both within and outside organizations.

\section{Details of the coding process}

The coding process entailed eight coding meetings between the two coders. Firstly, each coder independently coded 3e, then 6, then 12 interviews to identify the different phases, the nature of adjustments exhibited by the coach ( $E, V$, or $L$ ), and the stakeholder to whom the reactions were directed (coachee, organization, professional body, or other). This sequencing $(3,6$, then 12) allowed for comparisons of the coding, a discussion of the differences, and a refinement of the codes. This first coding sequence was extended to 10 more interviews, and any remaining issues were discussed between the two coders and consensually resolved.

Finally, the last 15 interviews were coded by one of the coders, with the other coder reviewing the coding. At this final stage, five codes required inter-coder discussion, which was followed by a consensus. Table 3 below gives some sample quotes for the different reactions. 
Table 3. Illustrative quotes and related coding of coaches' reactions towards different stakeholders

\begin{tabular}{ll} 
Coach's reaction & Sample quote \\
\hline Exit & I asked to meet with the manager who had requested the coaching for my client, and I told her: "I am not willing to continue the coaching \\
& job as it has moved away from the scope initially defined." She insisted that I continue. But I replied: "No, for me this is not OK. This is not \\
& OK because I do not feel aligned." Hence, I terminated the contract. (Lucy-ICF6-Exit from the organization) \\
& I mean, in this situation the coachee was really in danger. And for me, protecting her was actually more important than respecting the \\
& code of conduct. (Flora-SFC5-Exit from professional bodies) \\
\hline Voice & I advised (the coachee) to talk to his manager and negotiate directly with her. (Bob -SFC5-Voice towards the coachee) \\
& I told the HR Manager I could not guarantee the results of the coaching intervention. (Maya-ICFI 6-Voice towards the organization) \\
\hline Loyalty & Clearly some of the espoused and historical values of this organization were disregarded, so I wanted to correct that. \\
& (Alex-SFC2-Loyalty towards the organization) \\
Supervision, and SFC is in the background as an institution. (Patricia-SFC5-Loyalty towards professional bodies) \\
To counterbalance what had happened (in coaching); I strengthened my involvement in the Green party. (Jose-SFCI4-Loyalty towards other \\
entities)
\end{tabular}

We now present our findings.

\section{Findings}

\section{Starting situation: A series of loyalty reactions to ensure compatibility between commitments}

At the start of the coaching jobs, coaches' commitments are experienced typically as compatible. However, this compatibility should not be seen as a given but rather the result of a series of adjustments, which mainly take the form of loyalty expressed towards a multitude of stakeholders.

\section{Commitments are compatible}

As they recount their incidents, interviewees mostly refer to a starting situation where their multiple commitments are experienced as compatible. This is well illustrated by Mila' (SFCI6), who expresses this compatibility in terms of the two "alliances" that are "key at the start of the intervention," "referring to the alliance with the coachee, but... also with the sponsoring organization." For her part, Flora (SFC6) reminded us that "coaching serves the interests of both the coachee and the client," as stipulated in the code of ethics of her coaching association. And when Sandro was asked, who he considered his main client, he replied: "I hold both."

This compatibility does not mean that the requests always match, however. Most interviewees highlighted potential discrepancies stemming from different "approaches" to an issue, multiple and hidden "agendas," even "a double language that you always find" in organizations. Patricia (SFC8) stated, "Typically, the manager will evaluate the issue in a certain way, and the collaborator will look at it from his own angle." But

\footnotetext{
I. As explained in the Research Methodology section, each situation coaches shared with us is briefly summarized in Table I.
}

managing multiple potentially conflicting requests is "part of the job of the coach" (Patricia), who should not be paralyzed by "potential gaps" but rather "tap into them." Marie (SFC 7) described it as "creating a dialogue" between two potentially different or opposing views.

\section{Compatibility is reached through a series of adjustments based on loyalty}

Marie's expression, "creating this dialogue between commitments," shows that this compatibility is not a given. Rather it results from small adjustments made by the coach; we define an "adjustment" as an action or decision in respect of one or more stakeholders that allows the compatibility to be maintained. And here, these adjustments are mostly expressed through loyalty. This means that coaches will use loyalty towards the different stakeholders in a dynamic way to ensure compatibility between their commitments. Take the example of Judy (SFC3), a coach who was asked by a director to help a manager "move forward" after he had been removed from the board of directors. Initially, this request seemed "straightforward" to Judy; it very much falls within the scope of a traditional coaching mission. However, she was surprised to hear the director talk about "relational skills deficiencies" and a tendency to "get swamped in details" when speaking about the manager. Despite her surprise, Judy stayed loyal to the director and his request. But when she first met the coachee and he made the unexpected request to do a "360"," Judy also accepted. In a way, by accepting the coachee's unexpected request and demonstrating this loyalty to the coachee without challenging him on the real rationale for a $360^{\circ}$, she compensated for her initial loyalty to the director and the way he had framed the request. This compensation is an example of an adjustment that a coach makes to allow compatibility between commitments. Judy's case therefore shows that in the starting 
situation there is compatibility between the commitments, but it is dynamically reached through a series of adjustments, in this case based on loyalty expressed towards a multitude of stakeholders.

\section{The incident: Commitments become incompatible}

However, at some point, the initially compatible commitments become incompatible; this is due to the eruption of specific events that the coach cannot reverse. And the difficulty or inability to maintain compatibility between commitments is a painful experience and is precisely what generates the ethical dilemma.

\section{Commitments become incompatible}

The shift towards incompatibility between commitments is illustrated by Judy (SFC3) using different terms such as "torn," "locked," and "in-between." Beth (ICF9) explained how she was "trapped" given the "dissensions" between the "two clients, the official client and the moral client," and "when the implicit contract takes over the explicit contract, it becomes unmanageable." These experiences are echoed in the interviews of other coaches, who described being "caught in a system of complex alliances," experiencing "a double jeopardy," "tension," "'cognitive dissonance," and "a major split."

\section{Events causing the incompatibility}

What are the sources of this incompatibility, which in turn causes disequilibrium after the initial equilibrium? They come from specific events in the coaching intervention that coaches cannot reverse. As we saw previously, whereas in the initial situation, coaches managed to restore equilibrium through adjustments, this time adjustments by coaches or stakeholders actually amplify the "split," "dissonance," or "tension" that coaches experience. These events can originate with the coachee. This was the case for Ryan (ICF7): when his coachee "exploded and cried," he realized that "there was a problem, ....(an) intense suffering, ... and it was not acceptable." Similarly, for Alex (SFC2), the "icing on the cake was when the manager burst into tears in his office, later followed by other colleagues crying too." The disturbance can emanate from a representative figure of the organization, such as the HR Manager or the coachee's manager. Patricia (SFC8) was struck by the HR Manager's request to use coaching to "get rid of" Helen through internal mobility and pass on the message that she should change her attire. She had to pinch her arm several times to make sure she had heard correctly. In Judy's case (SFC3), the disturbance was a kind of "pressure," a "threat" from the assistant director, which she referred to as a weapon hanging over her head. Finally, the disturbance can come from a change in context, whether organizational or at the macro level. This is exemplified by Mila's (SFCI6) situation: her coachee was moved to another department while the former unit continued to pay for the contract. She felt she was betraying the initial sponsor who paid her, and continuing would mean participating in organizational "power games."

In brief, when the incident occurs, the initially compatible commitments become incompatible because of events that coaches cannot reverse through adjustments, thus paving the way for ethical dilemma. This dilemma is therefore located in the incompatibility between the set of commitments.

\section{The ethical dilemma}

In concrete terms, what do ethical dilemmas look like for coaches? Let's explore the details of Bob's (SFC5) example. A large pharmaceutical company solicited Bob to provide external coaching to a doctor with managerial responsibilities inside the company and encountered collaboration issues with his boss, the department head. Bob, who met the boss during the initial three-party meeting, easily understood the difficulty his coachee was facing since he diagnosed the boss as both caring, "providing generous support to her employees," and very normative and strict, "highlighting in red the typos and errors in the reports handed out to her.' The coach's initial loyalty to the client was challenged by the doctor's announcement during the fourth meeting that the coaching intervention had made him realize he had no future in this pharmaceutical company and wanted to leave it. He then asked Bob to help him prepare his new career path. This situation was experienced as an ethical dilemma for Bob; he described himself as torn between staying within the boundaries of the contract, as requested by the code of conduct, and answering the doctor's request that he deemed legitimate given the organization's detrimental environment. Furthermore, it was impossible to honor both requests simultaneously.

Amy (ICFI5)'s coachee Natasha had transitioned to a new position with a "nice boss." The coaching situation was typical and started off quite smoothly. However, Natasha's situation started deteriorating progressively, and this led to an ethical dilemma for Amy. Natasha's boss became more challenging, and Natasha's husband attempted suicide. After a few weeks, Amy witnessed Natasha physically degrading, with much weight loss. Amy worried that Natasha might soon be a victim of burnout. Amy wondered whether she should report to HR Natasha's deeply personal and challenging situation. If she discloses this information, would she be betraying Natasha? On the contrary, wouldn't she be protecting her by this disclosure? Similarly, wouldn't it be a betrayal to her profession if she did not disclose anything? At the same time, wouldn't the sponsoring company expect Amy to report this extreme situation? For Caroline (SFCI5), the ethical dilemma revolved around 
disclosing secret information obtained during the coaching intervention that could be useful to the organization to understand the employee's situation: she had discovered that her client was an alcoholic.

Another typical ethical dilemma is when coaches question themselves about how far they should go in challenging a stakeholder without abusing their own power. This was Sandro's case (ICFIO). Sandro wondered whether it was appropriate to let his coachee know that he was feeling a lack of connection with her, or whether to keep quiet about it since sharing this insight would hurt her. Dorian (ICFI9) was also unclear about how far he could go, whether he could challenge the HR Manager about his (perceived) inappropriate request without jeopardizing the healthy relationships he had with both his coachee and the HR Manager.

\section{Resolution: Restoring compatibility through a series of combined voice, exit, and loyalty}

While the ethical dilemma emerges from the incompatibility between a set of commitments, its resolution involves restoring compatibility through adjustments. We found that to achieve this, coaches manifest a combination of voice and exit, and potentially loyalty at a later stage. We present each below, but it is important to note that they can be used in combination, and are interdependent, that is, one position supports another.

\section{Voice to restore compatibility between commitments}

Voice is very common. It entails sharing an assessment, an opinion, or a concern. In Laetitia's example (ICFI3), she decides to take the risk of challenging her coachee, "a very wealthy and influential politician in the region," about the rationale of his inconsistent behavior towards her (he is constantly changing the dates of their meetings). Diego (SFCI7) also confronts his coachee about his refusal to include the new boss in the coaching contract. In this case, voice was expressed towards the client, with many coaches declaring that voice towards the organization requires clarification of the objectives of their contract (Marie, Patricia): asking what might happen if the coaching is not successful (Tom), or sharing their assessment of a dysfunctional situation (Amanda, Mila, Maya, Samantha). Again, these adjustments are not given. They require "risk-taking" on the part of the coach. Pointing out dysfunctions can backfire on coaches, as they are often expected simply to complete the assigned mission. However, for Flora (SFC6), there is a "higher" rule that requires her to abandon her initial impartiality and speak up. "We cannot continue to enjoy a cup of tea while the barn is on fire," she explains.

\section{Exit to restore compatibility between commitments}

Another approach adopted by coaches to restore compatibility is exit. Mostly, this entails terminating their coaching contract. Exit is often used in combination with other positions, such as voice or loyalty. For instance, after first using voice to express her disagreement with the director about treating the midterm, three-way meeting as an evaluation session, Judy (SFC3) then uses exit when she decides that she will never again work for the company after completing her coaching mission. Bob (SFC5), having taken the time to think about a coachee's unexpected request to prepare for departure, explains to the coachee (voice) that he could not do so unless the coachee negotiates this new direction as part of the contract with the client-manager. When the coachee refuses to speak to his manager, Bob ends the coaching contract (exit from the coachee) to stay loyal to the organization.

\section{Loyalty to restore compatibility between commitments}

The third approach available to coaches is to reach out to specific stakeholders (such as a peer, a more experienced colleague, or a supervisor) for support and guidance or engage in a particular outlet (like the arts or sports), which will help restore and consolidate compatibility between commitments. This often happens in combination with the above two reactions of voice and exit. Coaches thereby demonstrate loyalty to these stakeholders. For example, supervisors and peers help "revisit the movie" of what previously happened, as explained by Monique (ICFI2): "What led to the conflict? How did the coach react and why? Could the coach have acted differently and why? What lessons are to be learnt for the future?" Bob (SFC5) cited the role of gardening, yoga, and meditation: practices that offer time and space to "step back and settle down." The loyalty reactions that coaches demonstrate towards such practices thus constitute actions that further help restore the balance they lost through the incident.

In brief, EVL represent adjustments, used alone or combined, to restore compatibility between commitments, which appears as a way to solve the ethical dilemma. Table 4 depicts the nature and role of the adjustments made throughout the ethical dilemma.

\section{Discussion: Making ethical decisions like a funambulist}

Our findings show that compatibility between commitments should not be taken for granted. Rather, achieving, maintaining, 
Table 4. Nature and role of adjustments in the emergence and resolution of the ethical issue

\begin{tabular}{|c|c|c|c|}
\hline & Starting issue & Incident & Resolution \\
\hline Nature of adjustments & Loyalty & Not applicable & $\begin{array}{l}\text { A combination of Voice, Exit, and } \\
\text { Loyalty }\end{array}$ \\
\hline Role of adjustments & $\begin{array}{l}\text { Adjustments ensure initial compatibility } \\
\text { between commitments. }\end{array}$ & $\begin{array}{l}\text { Lack of efficient adjustments to maintain } \\
\text { compatibility; compatibility is therefore challenged. }\end{array}$ & $\begin{array}{l}\text { Adjustments restore compatibility } \\
\text { between commitments. }\end{array}$ \\
\hline
\end{tabular}

and restoring compatibility requires the individual to make adjustments. These adjustments take the form of EVL reactions in our study, and when these adjustments do not work or prove impossible, ethical dilemmas surface. Therefore, as explained below, we build on the systemic framework (Bateson, 1972; Watzlawick et al., 1968) to define ethics as a kind of funambulism whereby, like a funambulist, the ethical decision maker manages an equilibrium "along the way," through a series of interrelated adjustments. We therefore suggest portraying ethics as an emergent system of practices, one that is made up of interrelated adjustments, which individuals use to maintain or restore the system's equilibrium, that is, compatibility between commitments. This contribution alludes to the dynamic and constructed nature of ethics (Simpson, 2009; Sonenshein, 2007, 2009), which we detail next.

\section{Understanding ethics as funambulism}

Building on the systemic framework, we portray an ethical dilemma as a type of disequilibrium that emerges from a coach's conflicting commitments and its resolution as the reestablishment of equilibrium in the system; that is, compatibility between commitments. This equilibrium is precisely restored by adjustments that take the form of exit, voice, or loyalty in our study.

Our research shows that multiple conflicting commitments can generate ethical dilemmas when individuals do not manage to maintain or restore their compatibility through adjustments. Using the vocabulary of the systemic framework described below, we can say that ethical dilemmas are experienced when the equilibrium between commitments is broken.

The systemic framework is used to characterize a field of analysis that has emerged and expanded over the past 70 years in the natural sciences (von Bertalanffy, 1968), as well as in the human sciences of macrosociology (Parsons, 195I), organization theory (Crozier \& Thoenig, 1976; Parsons, 1956), communication theory and therapy (Bateson, 1972; Watzlawick, Beavin Bavelas, \& Jackson, 1967), and management (Bonami, De Henin, \& Boqué, 1993; Kast \& Rosenzweig, 1972; Probst \& Ulrich, 1989; Reihlen, Klaas-Wissing, \& Ringberg, 2007; Schein, 2006). Inspired by research in biology and organisms, the rationale of systems thinkers in management has been to portray organizations as living units composed of interconnected elements, as opposed to single-lens "atomistic" (Bonami et al., 1993, p. 17) approaches that distinguish between and isolate objects (Probst \& Ulrich, 1989). A systemic framework fundamentally entails studying people's reactions "in their reciprocal articulation," with the assumption that "the significance of each reaction is acquired through its position in the overall system" (Labarrière, 1990, p. 2533). In other words, these reactions constitute a system, "a complex object, made of distinct components interrelated through a certain number of relationships" (Ladrière, 1995, p. 586).

Key to this systemic framework is the idea of equilibrium in a living system, an equilibrium portrayed as dynamic (Kast \& Rosenzweig, 1972). Equilibrium does not mean that the system remains as is; rather, it faces relatively minor changes that in fact contribute to its maintenance within delimited boundaries. And our findings suggest that ethical dilemmas emerge precisely from a breakdown in this dynamic equilibrium between commitments. This suggests portraying the ethical dilemma as the disequilibrium in the system of a coach's commitments and its resolution as the reestablishment of equilibrium in the system, expressed as the compatibility between commitments. This equilibrium is precisely restored by the adjustments that take the form of exit, voice, or loyalty in our study.

Combining the idea of equilibrium and adjustments, we use the metaphor of funambulism to describe the ethical decision maker as a funambulist who uses adjustments to maintain or restore equilibrium along the way. This is summarized in Figure 1.

Consequently, ethics becomes a system of interrelated adjustment "practices" (Simpson, 2009, p. 1329), which allude to the emergent approach to ethics (Sonenshein, 2009). While in dominant approaches, as pointed out by Sonenshein (2007), individuals are portrayed as reacting to ethical dilemmas and judging them by applying a pre-existing framework external to the individual, an emergent perspective portrays ethics as a practice that is dynamically constructed (Simpson, 2009) by the subject (Sonenshein, 2009) in interaction with others, with ethical meanings that are mutable, unpredictable, and always transforming (Reihlen et al., 2007). 


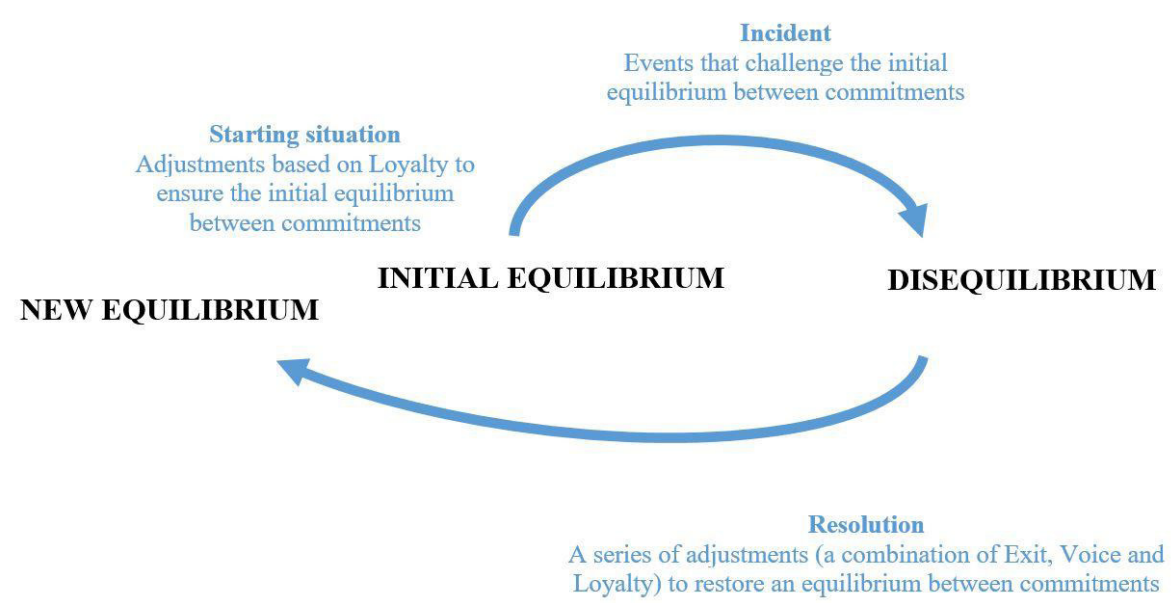

Figure I. Graphical representation of ethical decision-making maintaining equilibrium through adjustments

\section{Ethical criteria make sense in systems}

Our study shows that EVL, as adjustment mechanisms do not hold an intrinsic value. Rather this value is acquired through contributions to the system's equilibrium; challenging the traditional approach to the value and functions of EVL.

For instance, Hirschman himself paid much attention to exit and considered it the most efficient of the three: a perspective often favored by economists (Keeley \& Graham, 1991). Later, more attention was given to voice (Bryant, 2003; Keeley \& Graham, 1991); with Hirschman even recognizing that he has been "too timid" (Hirschman, 1980, p. 431) on the value of voice. The functions of loyalty appear to have been discussed less than those of exit and voice. Common to these approaches is a discussion of the value of exit, voice, or loyalty reactions in isolation, as isolated entities have an intrinsic value, independent from each other. Additionally, externally defined, objective criteria are used to gauge the (ethical) value of these feedback mechanisms - for example, Hirschman mostly referred to the profit criterion: how much the reaction prevents the firm from declining. However, based on our research, we suggest that EVL reactions need to be understood from a systemic perspective. Indeed, building on our findings, we see that the ethical value of an adjustment such as exit, voice, or loyalty lies in the decision maker's contribution to the maintenance or restoration of equilibrium between commitments. Adjustments therefore neither have an a priori value per se, nor can they be assessed in isolation. Rather, their value makes sense (Sonenshein, 2007) when considering their function within a system. This means that ethical criteria do not hold an intrinsic value but rather make sense in systems.

\section{Conclusion}

Given that employees increasingly face multiple commitments, more research is needed to understand the nature and mechanisms of conflicting commitments (Meyer, 2016). For this reason, we have explored how individuals make ethical decisions when they experience conflicting commitments. Our research shows that while it is true that compatibility between commitments is often a desired state (Meyer \& Herscovitch, 200I), it should not be taken for granted. Indeed, reaching, maintaining and restoring compatibility between commitments requires adjustments from the individual. Building on the systemic framework, we portray an ethical dilemma as the disequilibrium in the system of a coach's commitments, and their resolution as the reestablishment of equilibrium in the system, by maintaining compatibility between commitments. This equilibrium is precisely restored by adjustments that take the form of exit, voice, or loyalty in our study. Therefore, we have portrayed ethics as a series of practices akin to funambulism, where, like a funambulist, the ethical decision maker manages an equilibrium 'along the way,' through a series of interrelated adjustments. In summary, we portray ethics as an emergent system of practices, thus emphasizing the dynamic and constructed nature of ethics (Simpson, 2009; Sonenshein, 2007, 2009).

\section{References}

Arthur, N. (200 I). Using critical incidents to investigate cross-cultural transitions. International Journal of Intercultural Relations, 25(I), 4I-53. doi: 10.1016/50 I 47-1767(00)00041-9

Bachkirova,T. (20 17). Developing a knowledge base of coaching: Questions to explore. - PsycNET. In T. Bachkirova, G. Spence, \& D. Drake (Eds.), 
The SAGE handbook of coaching (pp. 23-4I). Sage. Retrieved from https://psycnet.apa.org/record/2017-07502-002

Bateson, G. (1972). Steps to an ecology of mind. University Press of Chicago. Becker, T. E. (20 I 6). Multiple foci of workplace commitments. In J. P. Meyer (Ed.), Handbook of employee commitment (pp. 43-55). Edward Elgar Publishing. Retrieved from https://www.elgaronline.com/view/edc oll/978 |7847 | | 733/978 |7847 | |733.000 | 3.xml

Becker, T. E., Kernan, M. C., Clark, K. D. \& Klein, H. J. (20।8). Dual commitments to organizations and professions: Different motivational pathways to productivity. Journal of Management, 44(3), I202-1225. doi: 10.1 1 77/0149206315602532

Biétry, F., Creusier, J., Laroche, P. \& Camus, S. (20I4). Perceived support, affective commitments and subjective career success: A person-centred approach.M@n@gement, 17(I),20-37. Retrieved from https://management-aims.com/index.php/mgmt/article/view/3934

Bonami, M., De Henin, B. \& Boqué, J. M. (1993). Management des systèmes complexes. Pensée systémique et intervention dans les organisations. De Boeck Université.

Bryant, M. (2003). Persistence and silence: A narrative analysis of employee responses to organisational change. Sociological Research Online, 8(4), I-I5. doi: 10.5 I53/sro.853

Butterfield, L. D., Borgen, W. A., Amundson, N. E. \& Maglio, A.-S. T. (2005). Fifty years of the critical incident technique: 1954-2004 and beyond. Qualitative Research, 5(4), 475-497. doi: I 0.1 I 77/ | 468794 I 05056924

Charreire Petit, S. (2008). Du whistleblowing à l'américaine à l'alerte éthique à la française: enjeux et perspectives pour le gouvernement d'entreprise. M@n@gement, I/(2), | |3-135. doi: 10.39/7/mana. 112.0113

Charreire Petit, S. \& Cusin, J. (2013). Whistleblowing and resilience: Analysis of an individual trajectory.M@n@gement, I6(2), |4I-175. Retrieved from https://management-aims.com/index.php/mgmt/article/view/4034

Chell, E. (2004). Critical incident technique. In C. Cassell \& G. Symon (Eds.), Essential guide to qualitative methods in organizational research (pp. 45-60). SAGE Publications.

Cooper-Hakim, A. \& Viswesvaran, C. (2005). The construct of work commitment:Testing an integrative framework. Psychological Bulletin, 13 I (2), 241-259. doi: 10.1037/0033-2909.131.2.241

Crozier, M. \& Thoenig, J.-C. (1976). The regulation of complex organized systems. Administrative Science Quarterly, 2 I (4), 547-570. doi: I0.2307/ 2391716

Czarniawska, B. (2017). A touch of nostalgia: On Albert O. Hirschman, my idol. M@n@gement, 20(5), 517-522. doi: 10.3917/mana.205.0517

deVaujany, F.-X., Leclercq-Vandelannoitte,A.\& Holt, R. (2020). Communities versus platforms: The paradox in the body of the collaborative economy. Journal of Management Inquiry, 29(4), 450-467. doi: I0.1 I77/ 1056492619832119

Derrida, J. (1992). The gift of death. University of Chicago Press.

Dowding, K., John, P., Mergoupis, T. \& Van Vugt, M. (2000). Exit, voice and loyalty: Analytic and empirical developments. European Journal of Political Research, 37(4), 469-495. doi: I 0. I 023/A: 007 I 34730724

Dubouloy, M. (2004). The transitional space and self-recovery: A psychoanalytical approach to high-potential managers' training. Human Relations, 57(4), 467-496. doi: I0.1 177/0018726704043896

Dunne, D. D. \& Dougherty, D. (20।6). Abductive reasoning: How innovators navigate in the labyrinth of complex product innovation. Organization Studies, 37(2), I3 I-159. doi: I0. I I77/0 I 708406 |560450 |

Fatien Diochon, P. \& Nizet, J. (20I5). Ethical codes and executive coaches. The Journal of Applied Behavioral Science, 5 I (2), 277-301. doi: I0.1 177 I 0021886315576190
Fatien Diochon, P. \& Nizet, J. (2019). Ethics as a fabric: An emotional reflexive sensemaking process. Business Ethics Quarterly, 29(4), 46I-489. doi: 10.1017/beq.2019.11

Flanagan, J. C. (1954). The critical incident technique. Psychological Bulletin, 5I (4). 327-356. doi: I0. I037/h006 I470

Fleming, P. (20 17). The human capital hoax:Work, debt and insecurity in the era of uberization. Organization Studies, 38(5), 691-709. doi: 10.1 177/0170840616686129

Galbraith, J. (1973). Designing complex organizations. Addison-Wesley Longman Publishing Co.

Garvey, B. (20I I). A very short, fairly interesting and reasonably cheap book about coaching. SAGE Publications.

George, E. \& Chattopadhyay, P. (2005). One foot in each camp: The dual identification of contract workers. Administrative Science Quarterly, 50(I), 68-99. doi: I0.2189/asqu.2005.50.1.68

Graßmann, C., Schermuly, C. C. \& Wach, D. (2019). Potential antecedents and consequences of negative effects for coaches. Coaching: An International Journal of Theory, Research and Practice, I2(I), 67-88. doi: I $0.1080 / 17521882.2018 .1489870$

Graßmann, C., Schölmerich, F. \& Schermuly, C. C. (2020). The relationship between working alliance and client outcomes in coaching: A meta-analysis. Human Relations, 73(I), 35-58. doi: 10.1177/0018 $7267 \mid 8819725$

Gray, D., Garvey, B. \& Lane, D. (2016). A critical introduction to coaching and mentoring. Sage Publications.

Greimas, J. (1966). Sémantique structurale. Recherche de méthode. Larousse.

Hirschman, A. O. (1970). Exit, voice, and loyalty: Response to decline in firms, organizations, and states. Harvard University Press.

Hirschman, A. O. (1980). "Exit, voice, and loyalty": Further reflections and a survey of recent contributions. The Milbank Memorial Fund Quarterly. Health and Society, 58(3), 430-453. doi: 10.2307/3349733

Hirschman, A. O. (1993). Exit, voice, and the fate of the German democratic republic: An essay in conceptual history. World Politics, 45(2), |73-202. doi: I0.2307/2950657

Hooghiemstra, R. \& van Manen, J. (2002). Supervisory directors and ethical dilemmas: Exit or voice? European Management Journal, 20(I), I-9. doi: 10.1016/S0263-2373(0 I)00 I04-9

ICF (2016). 2016 ICF Global Coaching Study. Executive Summary. Retrieved from https://coachingfederation.org/app/uploads/2017/12/ 2016ICFGlobalCoachingStudy_ExecutiveSummary-2.pdf

lordanou, I. \&Williams, P. (2017). Developing ethical capabilities of coaches. In T. Bachbirova, G. Spence, \& D. Drake (Eds.), The SAGE handbook of coaching (pp. 696-712). Sage Publications. Retrieved from https://www. researchgate.net/publication/310802183_Developing_Ethical_ Capabilities_of_Coaches

Jones, C., Parker, M. \& Ten Bos, R. (2005). For business ethics. Routledge. Retrieved from https://books.google.fr/books/about/For_Business_ Ethics.html?id=Jo_UMJOL3 | 4C\&redir_esc =y

Kammeyer-Mueller, J. D., Simon, L. S. \& Rich, B. L. (20 I2). The psychic cost of doing wrong. Journal of Management, 38(3), 784-808. doi: 10.1 1 777/0 | 4920631038| 133

Kast, F. E. \& Rosenzweig, J. E. (1972). General system theory: Applications for organization and management. Academy of Management Journal, I5(4), 447-465. doi: | 0.2307/255 |4 |

Keeley, M. \& Graham, J.W. (1991). Exit, voice, and ethics. Journal of Business Ethics, I 0(5), 349-355. doi: 10.1007/BF00383236

Kohlberg, L. (1973). The claim to moral adequacy of a highest stage of moral judgment. The Journal of Philosophy, 70( I 8), 630-646. doi: 10.2307/ 2025030 
Labarrière, P. J. (1990). Systèmes. In A. Jacob (Ed.), Encyclopédie philosophique universelle. II. Les notions philosophiques. Dictionnaire (pp. 2532-2533). PUF.

Ladrière, J. (1995). Système (Epistémologie). In Encyclopædia Britannica (Ed.), Encyclopaedia Universalis (pp. 585-588). Encyclopaedia Universalis.

Leighton, P. \& McKeown, T. (20I5). The rise of independent professionals: Their challenge for management. Small Enterprise Research, 22(2-3), | |9-130. doi: | 0.1080/I32 I5906.2015.1085627

Levinas, E. (1991). Otherwise than being. Duquesne University Press.

Louis, D. \& Fatien Diochon, P. (20।4). Educating coaches to power dynamics: Managing multiple agendas within the triangular relationship. Journal of Psychological Issues in Organizational Culture, 5(2), 31-47. doi: I0. 1002 / jpoc.21।40

Louis, D. \& Fatien Diochon, P. (2019). Complex situations in coaching: A critical case-based approach. Routledge.

Meyer, J. P. (2016). Employee commitment: An introduction and roadmap. In J. P. Meyer (Ed.), Handbook of employee commitment (pp. 3-12). Edward Elgar Publishing. Retrieved from https://www.elgaronline.com/ view/edcoll/978 |7847| | 733/978 |7847| |733.00009.xml

Meyer, J. P. \& Herscovitch, L. (200 I). Commitment in the workplace:Toward a general model. Human Resource Management Review, II (3), 299-326. doi: I0. I 0 I 6/S I 053-4822(00)00053-X

Miles, R. E. \& Snow, C. C. (1986). Organizations: New Concepts for New Forms. California ManagementReview, 28(3), 62-73. doi:10.2307/41I65202

Mintzberg, H. (1978). The structuring of organizations: A synthesis of the research. Palgrave MacMillan.

Nair, L. B. (20|8). Appraising scholarly impact using directed qualitative content analysis: A study of article title attributes in management research. Sage. doi: |0.4135/978|526444|4|

Natale, S. M. \& Diamante,T. (2005). The five stages of executive coaching: Better process makes better practice. Journal of Business Ethics, 59, 36|-374. doi: |0.2307/25 | 23569

Nelson William, A., Weeks, W. B. \& Campfield, J. M. (2008). The organizational costs of ethical conflicts. Journal of Healthcare Management, 53(I), 4|-52. doi: | 0. I097/00 | |55 |4-20080 |000-00009

Nizet, J. \& Diochon, P. F. (20I2). Comprendre les ambiguités du coaching, à l'éclairage du fonctionnalisme. Annales Des Mines - Gérer et Comprendre, I l 0(4), 24-33. doi: 10.39 |7/geco. I 10.0024

Olsen, K. M., Sverdrup, T., Nesheim, T. \& Kalleberg, A. L. (2016). Multiple foci of commitment in a professional service firm: Balancing complex employment relations. Human Resource Management Journal, 26(4), 390-407. doi: 10.1 I | |/1748-8583. 12109

Parmar, B. (20|4). From intrapsychic moral awareness to the role of social disruptions, labeling, and actions in the emergence of moral issues. OrganizationStudies, 35(8), | | 0 | - | | 26.doi: | 0. I | 77/0 | 708406 | 35 | 7595

Parsons, T. (195I). The social system. Free Press.

Parsons,T.( (1956). Suggestions for a sociological approach to the theory of organizations. Administrative Science Quarterly, I ( I), 63-85. doi: I0.2307/2390840

Pichault, F., Fatien Diochon, P. \& Nizet, J. (2020). Autonomy of independent professionals: A political process perspective. European Management Journal, 38(4), 623-633. doi: 10.1016/j.emj.2019.12.007

Piret, A., Nizet, J. \& Bourgeois, E. (1996). L'analyse structurale. De Boeck Université.

Probst, J. B. \& Ulrich, H. (1989). Pensée globale et management. Résoudre les problèmes complexes. Les Editions d'Organisation.

Reichers, A. E. (1986). Conflict and organizational commitments. Journal of Applied Psychology, 7 I (3), 508-5 I 4. doi: I0. I037/002 I-90 I 0.7I.3.508

Reihlen, M., Klaas-Wissing, T. \& Ringberg, T. (2007). Metatheories in management studies: Reflections upon individualism, holism, and systemism. M@n@gement, 10(3),49-69.doi: 10.3917/mana.103.0049
Reinecke, J. \& Ansari, S. (20 I5). What is a "fair" price? Ethics as sensemaking. Organization Science, 26(3), 867-888. doi: 10.1287/orsc.2015.0968

Rest, J. (1986). Moral development: Advances in research and theory. Praeger. Salman, S. (2008). La fonction palliative du coaching en entreprise. Sociologies Pratiques, 17(2), 43-54. doi: 10.39 I7/sopr:0 I7.0043

Salman, S. (2019). Towards a "client professionalization" process? The case of the institutionalization of executive coaching in France. Journal of Professions and Organization, 6(3), 286-303. doi: 10.1093/ jpo/jozOI2

Schein, E. H. (2006). From brainwashing to organizational therapy:A conceptual and empirical journey in search of "systemic" health and a general model of change dynamics. A drama in five acts. Organization Studies, 27(2), 287-30 I. doi: | 0.1 1 177/017084060606/831

Schwartz, M. S. (2016). Ethical decision-making theory: An integrated approach. Journal of Business Ethics, 139(4), 755-776. doi: I0.1007/ sl055।-0|5-2886-8

Sekerka, L. E., Godwin, L. N. \& Charnigo, R. (20।2). Use of balanced experiential inquiry to build ethical strength in the workplace. Journal of Management Development, 3/(3), 275-286. doi: I0.1 108/0262I7 II211208907

Simpson, B. (2009). Pragmatism, mead and the practice turn. Organization Studies, 30( I 2), | 329-1347. doi: | 0.1 177//017084060934986 |

Sonenshein, S. (2007). The role of construction, intuition, and justification in responding to ethical issues at work: The sensemaking-intuition model. The Academy of Management Review, 32, 1022-1040. doi: 10.2307/ 20159354

Sonenshein, S. (2009). Emergence of ethical issues during strategic change implementation. Organization Science, 20(I), 223-239. doi: I0.1287/ orsc. 1080.0364

Stein, I. F. (2009). Which hat am I wearing now? An evidence-based tool for coaching self-reflection. Coaching: An International Journal of Theory, Research and Practice, 2(2), 163-175. doi: 10.1080/1752। 8 80903102233

Swart, J., Kinnie, N., van Rossenberg, Y. \& Yalabik, Z.Y. (20 I4). Why should I share my knowledge? A multiple foci of commitment perspective. Human Resource Management Journal, 24(3), 269-289. doi: I 0.1 I I I/ 1748-8583. 12037

von Bertalanffy, L. (1968). General system theory. Braziller.

Watzlawick, P., Beavin Bavelas, J. \& Jackson, D. (1967). Pragmatics of human communication: A study of interactional patterns, pathologies and paradoxes. Language Arts \& Disciplines.

Watzlawick, P., Beavin Bavelas, J. \& Jackson, D. D. (1968). Pragmatics of human communication: A study of interactional patterns, pathologies, and paradoxes. WW Norton \& Company. Retrieved from https://books. google.fr/books?id=CetbtgEACAAJ\&dq=Pragmatics + o $f+H u-$ man+Communication:+A+Study+of+Interactional+Patterns, + Pathologies+and + Paradoxes\&hl=fr\&sa $=$ X\&ved $=0$ ahUKEwiA5PfOmK_jAhUxA2MBHSOwBeUQ6AEIMzAB

Western, S. (20I2). Coaching and mentoring: A critical text. Sage Publications. Western, S. (2017). The key discourses of coaching. In T. Bachkirova, G. Spence, \& D. Drake (Eds.), The SAGE handbook of coaching (pp. 42-6I). Sage Publications.

Whelan, G., de Bakker, F. G. A., Den Hond, F. \& Muthuri, J. N. (20 I9). Talking the walk: The deflation response to legitimacy challenges. M@n@ gement, 22(4), 636-663. doi: I0.39 I7/mana.224.0636

Yalabik, Z.Y., van Rossenberg, Y., Kinnie, N. \& Swart, J. (2015). Engaged and committed? The relationship between work engagement and commitment in professional service firms. The International Journal of Human Resource Management, 26(I2), | 602-1621 . doi: I0. 1080/09585 I92.20 I 4.953972 


\section{Appendix I: Interview Guide}

Translated from French by the Authors

\section{Introduction}

- Thank you again for volunteering to do this interview related to a study on ethics in the practice of coaching. Could you detail why you have volunteered for this interview? See if this relates to the specific topic of ethics, and why. When relevant, ask questions about the frequency of ethical dilemmas faced by the coach.

- Could you briefly present your current professional activity? If needed, follow-up questions on years of experience in coaching, practice of individual/team coaching, SFCoach/ICF Status, etc.

\section{Ethics scenario}

Now, I am going to ask you to think back to a time when you were faced with an ethical challenge in your coaching practice. An example might be that you were in a situation where there was a conflict between doing what you thought you should do and what the coachee, sponsor, the SFC/ICFF, or your peers suggested. This might involve a conflict between your own values and the organization's goals. The situation may have made it difficult for you to act; to know what to do, or to determine how to resolve the situation. As you think back about experiences that you have encountered while on the job, this was a time when you may have been unsure how to act, or did not know what to do. The situation was likely undesirable, based upon the risks you perceived to be present. To summarize, the experience presented is an ethical issue and, at the time, none of the options seemed particularly favorable.

Can you share with me:

(I) What was the ethical challenge?

(2) What were you thinking at the time?

(3) What were you feeling at the time?

Follow-up questions:

- Why do you consider this situation as raising an ethical issue?

- How would you summarize the ethical dilemma?

- What supported or curtailed your ability to engage in an ethical action?

- What about SFCoach/ICFF: Did this association support or curtail your decision to act? ... and how?

- Has the way you coach changed as a result of this ethical dilemma? If yes, how?

- I have asked you the questions that I prepared. Is there anything else that you would like to add about ethics in your practice as a coach? 